\title{
Are Cardiovascular Diseases BAD FOR ECONOMIC GROWTH?
}

\author{
MARC SUHRCKE \\ DIETER URBAN
}

\begin{abstract}
CESIFO WORKING PAPER NO. 1845
CATEGORY 5: Fiscal Policy, MaCROECONOMICS AND GROWTH

NOVEMBER 2006
\end{abstract}

An electronic version of the paper may be downloaded

- from the SSRN website:

- from the RePEc website:

www.SSRN.com

- from the CESifo website:

www.RePEc.org

www.CESifo-group.de 


\title{
Are Cardiovascular Diseases Bad FOR ECONOMIC GROWTH?
}

\begin{abstract}
We assess the impact of cardiovascular disease (CVD) mortality on economic growth, using a dynamic panel growth regression framework taking into account potential endogeneity problems. We start from a worldwide sample of countries for which data was available and detect a non-linearity in the influence of working age CVD mortality rates on growth across the per capita income scale. We then split the sample (according to the resulting income threshold) into low- and middle-income countries on one hand, and high-income countries on the other hand. In the latter sample we find a robust negative contribution of increasing CVD mortality rates on subsequent five-year growth rates. Not too surprisingly, we find no significant impact in the low- and middle-income country sample.
\end{abstract}

JEL Code: I10, O47.

Keywords: cardiovascular disease, growth empirics, dynamic panel data estimator.

$\begin{array}{cc}\text { Marc Suhrcke } & \text { Dieter Urban } \\ \text { World Health Organization } & \text { Institute for International Economic Theory } \\ \text { European Office for Investment for Health } & \text { FB03 } \\ \text { \& Development } & \text { Johannes Gutenberg University Mainz } \\ \text { Campo Santo Stefano } & 55099 \text { Mainz } \\ \text { San Marco 2847 } & \text { Germany } \\ \text { 30124 Venice } & \text { dieter.urban@uni-mainz.de } \\ \text { Italy } & \\ \text { msu@ihd.euro.who.int } & \end{array}$

The paper does not represent necessarily the views of the institutions the authors are affiliated to. 


\section{Introduction}

There is abundant evidence that cardiovascular disease (CVD) and non-communicable disease (NCD) more generally are no longer mere "diseases of affluence". CVD kills nearly three times as many people in developing countries each year as HIV, tuberculosis, and malaria combined, and it accounts by far for the predominant share of overall mortality in developed countries. The main question that this paper seeks to address is therefore: are CVDs bad for economic growth?

Theoretically, ill-health may not only reduce the supply and productivity of labor but can also impede human capital accumulation. Hence, a poor health status would negatively impact individual and social welfare both through the utility function and through a lower growth rate (and level) of national per capita income. The empirical literature on the role of health in explaining the variation in growth rates (or levels) of per capita incomes has grown substantially in recent years ${ }^{2}$ - with the overall finding that health - when measured as life expectancy or adult mortality - enters as one of very few robust predictors of subsequent economic growth (Levine and Renelt 1992; Sala-i-Martin et al. 2004) ${ }^{3}$. However, research in this area has so far focused either on general health indicators (i.e., life expectancy, adult mortality) or on specific diseases most characteristic of developing countries. As for the latter, there is, for instance, evidence on the impact of malaria (Gallup and Sachs 2001), HIV/AIDS (Dixon et al. 2001), malnutrition (Weil 2005), and tuberculosis (Delfino and Simmons 1999) on economic growth.

\footnotetext{
${ }^{2}$ For extensive overviews see e.g. Commission on Macroeconomics and Health (2001) and López-Casasnovas et al. (2005).

${ }^{3}$ A recent qualification is by Acemoglu and Johnson (2006).
} 
While the vast majority of studies examines a worldwide sample, it is not obvious whether the same relationship exists between health and economic growth for rich countries as it does for poor countries. Indeed, Rivera and Currais (1999a, b), for example, find that an increase in life expectancy reduces economic growth rates among OECD countries. ${ }^{4}$ Therefore, it seems important to pay particular attention to whether there are sample breaks and, if so, where they occur. To the best of our knowledge, only Bhargava et al. (2001) determine endogenously the sample breakpoint. They establish a threshold in terms of per capita income below which a higher adult survival rate is positively affecting growth. Above the (relatively low) per capita income threshold the relationship switches signs.

To the best of our knowledge, no study has hitherto explored in some more depth the growth implications of the particular type of diseases that account for the largest disease burden in high-income countries, and for an already substantial and fast growing burden in developing countries, i.e., non-communicable disease $(\mathrm{NCD})^{5}$. The present paper fills this gap by examining the growth impact of cardiovascular disease (CVD), which is the disease that accounts for the greatest share of the NCD burden ${ }^{6}$. We follow Bhargava et al. (2001) in taking into particular account the potential difference between developed and developing countries, regarding the growth impact of this specific health indicator.

A priori, there is a lot to suggest that CVD might "matter" in economic terms.

First, a series of recent reports has highlighted the substantial and growing public health importance of CVD (Jamison et al 2006; WHO 2005). A distinctive feature of CVDs (as well as some other non-communicable diseases) is that it causes morbidity and, hence, potential

\footnotetext{
${ }^{4}$ However, Knowles and Owen $(1995,1997)$ find a positive correlation when replacing life expectancy by public health expenditure as a proxy for "health".

${ }^{5}$ It has come to be widely accepted that the term "non-communicable disease" is a somewhat unfortunate choice. Increasingly, NCDs are being called "chronic disease" in light of long duration. (WHO 2005).

${ }^{6}$ According to latest WHO estimates CVDs accounted for $51 \%$ of overall mortality due to NCDs in low- and middle-income countries in 2005 (WHO 2006).
} 
productivity decline years or even decades ahead of death ${ }^{7}$. Second, a recent review of the economic impact of chronic disease has synthesized a significant number of cost-of-illness studies highlighting the substantial economic magnitudes involved in CVDs and the related risk factors (Suhrcke et al. 2005) ${ }^{8}$. Third, the same review also summarized the microeconomic evidence on the labor market impact of chronic disease (and relevant risk factors).$^{9}$

The question then imposes itself whether on top of the obvious epidemiological evidence, the cost of illness as well as the microeconomic evidence, there may also be a macroeconomic impact of CVDs.

The present paper assesses the impact of CVD mortality on economic growth, adopting a panel growth regression framework, taking into account the potential endogeneity of CVDs. We are thereby careful in proxying CVD disease by its mortality rate among the working age cohort to capture as close as possible the impact of the disease on worker productivity. As in Bhargava et al. (2001), we start from a worldwide sample of countries for which data was available and detect a non-linearity in the influence of CVD on growth across the per capita income scale while controlling at the same time for more general health indicators. Then, we split the sample (according to the resulting income threshold) into low- and middle-income countries on one hand, and high-income countries on the other hand. In the latter sample we find a fairly robust negative contribution of increasing CVD mortality rates on subsequent five-year growth rates. Not surprisingly, we find no significant impact in the low- and middleincome country sample. Taken literally, this implies that as countries grow richer they should seek to avoid that what used to be "diseases of affluence" does not end up as obstacles to (even greater) affluence.

\footnotetext{
${ }^{7}$ This feature of CVDs also helps prevent allegations of reverse causality in our growth regression framework adopted below.

${ }^{8}$ See also Petersen et al (2005) for cost-of-illness estimates for all European Union member-states.

${ }^{9}$ On the economic consequences of CVDs see also Leeder et al. (2004).
} 
The paper is structured as follows. Section 2 argues why CVD may be of particular importance in explaining income growth; section 3 describes the empirical methodology, section 4 presents and discusses the results. The final section concludes.

\section{Cardiovascular disease}

Why should cardiovascular disease matter for growth? Traditionally, just like noncommunicable diseases (NCDs) in general, CVDs have been considered by many as a "disease of affluence" - a consequence rather than a determinant of economic development. Moreover, the economic importance of NCDs (or CVDs in particular) has typically been downplayed as it (allegedly) affected predominantly people beyond retirement age.

However, such notions of "conventional wisdom" fail to correctly characterize the contemporary epidemiological reality (Ezzati et al. 2005). First, NCDs already account for a larger share of mortality than communicable diseases and child and maternal disease taken together in all but the low income countries (see Figure 1). The richer the country, however, the greater the share of mortality accounted for by NCDs (and CVDs), which is why we expect stronger evidence on the impact of CVD on income growth for high-income countries than for low- and middle-income countries. ${ }^{10}$

Second, a very large share of NCD and CVD mortality is actually occurring well before retirement age (see Table 1). For example, 31\% of all CVD caused death falls into the age group younger than 65 years, even in low- and middle-income countries. When taking into

\footnotetext{
${ }^{10}$ Figure 1 only gives a recent snapshot of the disease burden at one point in time. It is important to emphasise that recent trends unambiguously show the morbidity and mortality burden caused by CVDs (and NCDs) progressing at an increasing speed not only in high-income countries but also in developing countries (Jamison et al, 2006).
} 
consideration that death is usually preceded by a period of morbidity, the disease burden falls even more into the working age group. Almost two thirds of the mortality and morbidity (measured in Disability Adjusted Life Years - DALYs) due to CVDs occurs before age 65.

Figure 1: Causes of death by World Bank income group (2002)

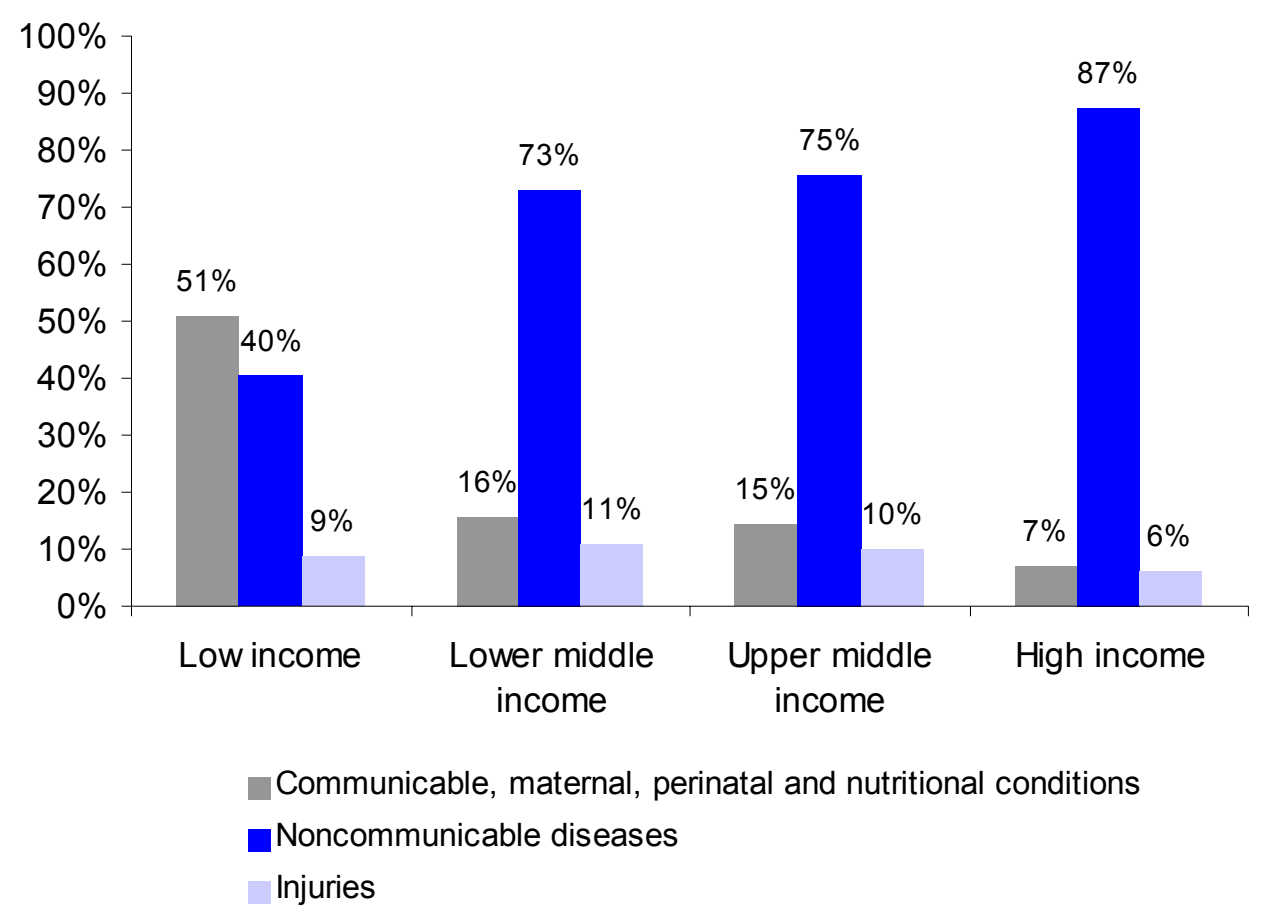

Source: WHO (2006)

Table 1: Share of disease burden falling before age 65, low and middle income countries

$\begin{array}{lcc}\text { Disease category } & \text { Deaths } & \text { DALYs } \\ \text { All NCDs } & 39 \% & 81 \% \\ \text { Cardiovascular disease } & 31 \% & 62 \% \\ \text { Communicable, maternal, } & 89 \% & 98 \% \\ \text { perinatal and nutritional } & & \\ \text { conditions } & & \\ \text { Source: WHO (2006). } & & \end{array}$

In light of this purely epidemiological evidence, it is not hard to imagine that there could well be a significant macroeconomic impact on labor supply, productivity, population growth, physical and human capital accumulation, and income in levels and growth rates. Labor 
supply is directly affected since morbidity usually precedes death. Affected workers do not only drop out of the workforce, but impose a health care burden on others reducing income and growth, for example, through distortionary taxation or health insurance premia to finance health care. Workers in ill-health may still work but at a reduced effort level, since the disease may affect their work ambition and durability, which in turn reduces average worker productivity. Worker productivity has not only an impact on the level of income but also on its growth rate, because worker productivity affects immediately the return on investment, capital accumulation and eventually income growth. Not only morbidity, but also life expectancy itself may have an impact on income in levels and growth. Since education is a fixed cost in the early stage of life that needs to be covered by education-wage premia over all later stages of working life, the return to human capital accumulation is negatively affected by a reduction in the expected working-age lifetime (Kalemli-Ozcan et al. 2000). A lower rate of human capital accumulation then again leads to reduced income growth. An increase of life expectancy also influences the fertility choice according to Soares (2005) which in turn affects the population growth rate and income growth (in a world with less than perfect international capital markets).

Figure 1 has suggested that despite its unquestionable global importance there may be significant differences between developing and developed countries in that communicable diseases are relatively more important for low-income countries and non-communicable diseases relatively more important for high-income countries. Since the study of Bhargava et al. (2001) pays particular attention to such structural breaks, we adopt its methodology and its control variables as a starting point. 


\begin{tabular}{|c|c|c|}
\hline $\begin{array}{l}\text { Variable } \\
\text { Abbreviation }\end{array}$ & Description & Source \\
\hline GDP p.c. & GDP per capita in PPP & $\begin{array}{l}\text { Penn World Tables } \\
6.0 \text { (rgdpl) }\end{array}$ \\
\hline Openness & Sum of exports and imports divided by GDP & $\begin{array}{l}\text { Penn World Tables } \\
\text { 6.0. (openk) }\end{array}$ \\
\hline Open 1965-90 & $\begin{array}{l}\text { Dummy with value one if country has } \\
\text { granted access to its home market during } \\
1965 \text { until } 1990\end{array}$ & $\begin{array}{l}\text { Gallup and Sachs } \\
\text { (1998) }\end{array}$ \\
\hline Investment rate & Net investment per GDP & $\begin{array}{l}\text { Penn World Tables } \\
6.0 \text { (ki) }\end{array}$ \\
\hline Adult mortality rate & $\begin{array}{l}\text { Probability of a } 15 \text {-year-old of dying before } \\
\text { age } 60 .\end{array}$ & $\begin{array}{l}\text { World Develop- } \\
\text { ment Indicators }\end{array}$ \\
\hline Fertility rate & $\begin{array}{l}\text { Number of children born to a woman that } \\
\text { lives to the end of her child-bearing age }\end{array}$ & $\begin{array}{l}\text { World Develop- } \\
\text { ment Indicators }\end{array}$ \\
\hline Secondary education & $\begin{array}{l}\text { Share of working age population with } \\
\text { secondary schooling or higher education }\end{array}$ & $\begin{array}{l}\text { Barro and Lee } \\
(2000)\end{array}$ \\
\hline Density of doctors & Number of physicians per 1000 inhabitants & $\begin{array}{l}\text { World Develop- } \\
\text { ment Indicators }\end{array}$ \\
\hline Injury mortality rate & $\begin{array}{l}\text { Mortality rate by injury per } 1000 \text { inhabitants } \\
\text { in working age }\end{array}$ & $\begin{array}{l}\text { WHO mortality } \\
\text { database }\end{array}$ \\
\hline CVD & $\begin{array}{l}\text { Cardiovascular Disease mortality rates per } \\
1000 \text { inhabitants in working age }\end{array}$ & $\begin{array}{l}\text { WHO mortality } \\
\text { database }\end{array}$ \\
\hline $\begin{array}{l}\text { Non-communicable } \\
\text { desease mortality rate }\end{array}$ & $\begin{array}{l}\text { Non-communicable disease mortality rates } \\
\text { per } 1000 \text { inhabitants in working age }\end{array}$ & $\begin{array}{l}\text { WHO mortality } \\
\text { database }\end{array}$ \\
\hline $\begin{array}{l}\text { Old age dependency } \\
\text { ratio }\end{array}$ & Old age ( 65 to over 95$)$ on total population & $\begin{array}{l}\text { World } \\
\text { Development } \\
\text { Indicators }\end{array}$ \\
\hline
\end{tabular}

We follow Bhargava et al. (2001) in applying panel data in five year intervals from the year 1960 until 2000 to avoid business cycle regularities to influence our results. The data are PPPadjusted GDP per capita and its 5-year time lag, the average degree of openness in between 
1965 and 1990 from Gallup and Sachs (1998), and 5-year lagged values of the investment rate, fertility rate, adult mortality rate and our variable of interest: CVD mortality rate of the working age population. We also use an interaction term of CVD mortality with lagged GDP per capita. Instead of the adult mortality rate, Bhargava et al. (2001) have used the adult survival rate, which is not publicly available. The data description, variable abbreviations, and sources are summarized in Table 2 that contains also additional variables that entered our analysis beneath.

Table A1 in the appendix gives summary statistics of each variable. Since we estimate a dynamic panel regression, and it is known that a standard OLS estimator is inconsistent in this case, we pay particular attention to the estimation methodology that is described next.

\section{Empirical methodology}

A panel growth regression model can be written in a general form as follows:

$$
y_{i t}=\sum_{l=1}^{p} \alpha_{l} \cdot y_{i, t-l}+\beta_{0}+\beta_{1} \cdot x_{i, t-1}+\beta_{2} \cdot z_{i, t-1}+\eta_{i}+\varepsilon_{i t}, \quad \text { for } \quad \mathrm{t}=1+\mathrm{p} \ldots \mathrm{T},
$$

where $y_{i t}$ is GDP per capita of country $i$ at time $t=1 . . T, x_{i t}$ is a vector of pre-determined control variables, $z_{i t}$ is a vector of exogenous control variables, $\eta_{i}$ an i.i.d. country-specific random effect, $\varepsilon_{i t}$ is the usual i.i.d. error term (possibly heteroscedastic but not autocorrelated), and $\beta_{j}, j=0,1,2$, and $\alpha_{l}, l=1, \ldots, p$, are the regression coefficients with $\left|\sum_{l=1}^{p} \alpha_{l}\right| \leq 1 .{ }^{11}$ The initial value of the dynamic process is assumed to be an i.i.d. random deviation from the steady state value. The time dimension of panel growth regressions was typically chosen to be 5 or 10

\footnotetext{
${ }^{11}$ If a unit root exists, i.e. $\left|\sum_{l=1}^{p} \alpha_{l}\right|=1$, then the Blundell and Bond (1998) estimator is still consistent but no longer efficient, as has been shown in Binder et al. (2003). The convergence rate can be obtained as $\alpha_{1}-1$ if $\mathrm{p}=1$.
} 
year periods to avoid short term business cycle components to influence the convergence rate (see e.g. Islam, 1995, Caselli et al., 1996, and Bond et al. 2001).

A pre-determined (endogenous) covariate is defined as a random variable that is allowed to depend on past values of GDP per capita, but not on future GDP per capita. When allowing for pre-determined variables $\mathrm{x}_{\mathrm{it}}$, the reverse causality from past values of GDP to $\mathrm{x}_{\mathrm{it}}$ is fully controlled for and the regression coefficient measures only the marginal effect from contemporary values of $\mathrm{x}_{\mathrm{it}}$ to future values of GDP per capita. Hence, a regression coefficient of a pre-determined variable measures causality in a Granger sense.

For example, when assuming our variable of interest CVD to be pre-determined, we take into consideration that the population in richer societies has a higher probability of CVD. The regression coefficient, however, filters this reverse causality, and measures only the impact that CVD today has on future economic growth assuming that today's occurrence of CVD is not depending on the prospect of future growth. However, the last assumption is not a binding constraint for our estimations, since it is not perceivable that life style adjusts before a change of income.

Nickel (1981) has shown that an FE-estimator on (1) is inconsistent, when the time dimension is small, because there is a correlation of the group mean of the error term with the lagged dependent variable. Moreover, Trognon (1978) has shown that an OLS-estimator is also inconsistent, because the lagged dependent variable is correlated with the random effect. The direction of bias is generally not known without further information on the covariance matrix of all variables, although closed form solutions of the bias term exist. 
Arellano and Bond (1991) recommend a one-step GMM-system estimator built on the following generalized moment conditions

$E\left[W_{i}^{\prime} \Delta \varepsilon_{i}\right]=0$

with the instrument matrix

$W_{i}=\left[\begin{array}{cccc}\left\lfloor y_{i 1} x_{i 1} \ldots x_{i p} z_{i 1} \ldots z_{i T}\right\rfloor & 0 & \ldots & 0 \\ 0 & {\left[y_{i 1} y_{i 2} x_{i 1} \ldots x_{i, p+1} z_{i 1} \ldots z_{i T}\right]} & \ldots & \ldots \\ \ldots & \ldots & \ldots & 0 \\ 0 & \ldots & 0 & {\left[y_{i 1} \ldots y_{i, T-p-1} x_{i 1} \ldots x_{i, T-1} z_{i 1} \ldots z_{i T}\right]}\end{array}\right]$

and $\Delta \varepsilon_{i}$ denotes the (T-1-p)-dimensional vector of first-differenced error terms. All elements of the matrix $\mathrm{W}_{\mathrm{i}}$ are valid instruments, because the lagged values of $2^{\text {nd }}$ and higher order of the dependent variable are not correlated with the first differenced error term, where firstdifferencing whipes out the random effect.

Blundell and Bond (1998) point out a weak-instrument problem (see Staiger and Stock, 1997, and Hahn and Hausman, 2002) that is most severe, whenever the dependent variable follows a near-unit root process or whenever the variance of the random effect is large relative to the variance of the error term, and suggest the additional moment conditions

$E\left[\Delta y_{i, t-1}{ }^{\prime}\left(\eta_{i}+\varepsilon_{i t}\right)\right]=0$,

for $t=p+1, \ldots, T$. The moment conditions in (3) hold, because lagged first differences of the dependent variable have differenced out the random effect and are not correlated with the contemporary error term.

As usual in GMM estimation, the generalized moments (2) and (3) are replaced by their sample estimates and the GMM criterion function over all moment conditions is minimized with respect to all regression coefficients. Because the moment conditions (2) and (3) imply that observations are taken twice (in level and first differences), the applied solution is 
identical to a system GMM estimator on a regression system of variables in levels and first differences.

The covariance matrix of the GMM criterion function depends on the regression estimates. Hence, a heteroscedasticity consistent one-step estimator replaces the estimated covariance matrix with an approximation (see Roodman, 2004, for details). A heteroscedasticity consistent two-step estimator uses the estimates of the second step to obtain an estimated moment covariance that is used to minimize the GMM criterion function again and obtain the more efficient two-step estimator. However, Arellano and Bond (1991) point out that there is a severe small sample bias of the covariance matrix of the regression coefficients, when applying the two-step GMM system estimator and recommend to use the one-step estimator. However, Windmeijer (2000) has developed a small sample correction to the regression coefficient covariance matrix. Hence, we will apply both the one-step system GMM estimator and the two-step system GMM estimator with small sample correction.

Bhargava et al. (2001) apply the Bhargava and Sargan (1983) dynamic panel estimator. While this estimator has similar statistical large sample properties and we are not aware of small sample Monte Carlo study comparisons, we prefer the Blundell and Bond (1998) estimator both, because its software is available for free ${ }^{12}$ and a larger number of applications exist such that more experience has been gained in applications.

\footnotetext{
${ }^{12}$ We thank David Roodman for his STATA 8.0 module xtabond2, which is used in this study. Of course, we take sole responsibility for any possible remaining errors in the program.
} 


\section{Results}

We begin with a GMM one-step system estimation of the baseline specification of Bhargava et al. (2001), i.e. we regress GDP per capita on its 5 -year time $\operatorname{lag}^{13}$, the average degree of openness in between 1965 and 1990 from Gallup and Sachs (1998), and 5-year lagged values of the investment rate, fertility rate, adult mortality rate and our variables of interest: CVD mortality rate of the working age population and its interaction term with lagged GDP per capita. Instead of the adult mortality rate Bhargava et al. (2001) have used the adult survival rate, which is not publicly available. A dummy variable for tropic countries as well as an interaction term of the survival rate and the lagged income level is left out, too, because both variables turned out to be insignificant for our sample, which is due to smaller coverage of observations caused by missing observations on CVD. There are few countries in our sample that are below the income threshold reported in Bhargava et al. (2001) which splits the sample into one group of countries with a positive and another with a negative impact of the survival rate on growth. Moreover, there are few countries in tropic regions that report CVD mortality rates.

The first specification in Table 3 uses the 1-step GMM-system estimator with the first and second lag of the instrumented covariates as instruments. When choosing the lag number of instruments, a trade-off was taken into consideration between increased efficiency of additional instruments and an aggravation of the weak-instrument problem, if additional time lagged instrumental variables are only weakly correlated with the instrumented covariate. ${ }^{14}$

\footnotetext{
${ }^{13}$ This is equivalent to estimating the growth rate of per capita income on its initial level. One just needs to subtract one from the coefficient on the initial income level, while all standard errors remain unaffected.

${ }^{14}$ See Hahn and Hausman (2002) and Staiger and Stock (1997) for discussions of the weak-instrument problem and Arellano and Bond (1991) and Blundell and Bond (1998) for a discussion of increased efficiency of additional instruments.
} 
Apart from the lagged dependent variable, we also use GMM instruments for the investment rate, which is suspected by Bhargava et al. (2001) to be endogenous.

Table 3: Full Sample

\begin{tabular}{|c|c|c|c|c|c|}
\hline Dep. income p.c. & $\begin{array}{r}\text { GMM } \\
\text { CVD } \\
\text { exogenous } \\
(1)\end{array}$ & $\begin{array}{r}\text { GMM } \\
\text { CVD } \\
\text { endogenous } \\
(2)\end{array}$ & $\begin{array}{r}\text { GMM-small } \\
\text { sample } \\
\text { correction } \\
(3)\end{array}$ & OLS & (5) \\
\hline Lagged income p.c. & $\begin{array}{c}1.71^{* * *} \\
(5.27)\end{array}$ & $\begin{array}{r}1.26^{* * * *} \\
(6.35)\end{array}$ & $\begin{array}{c}1.34^{* * *} \\
(5.96)\end{array}$ & $\begin{array}{l}1.06^{* * * *} \\
(11.42)\end{array}$ & $\begin{array}{l}1.06^{* * *} \\
(7.41)\end{array}$ \\
\hline Open 1965-90 & $\begin{array}{l}0.02^{*} \\
(1.69)\end{array}$ & $\begin{array}{l}0.01^{* *} \\
(2.20)\end{array}$ & $\begin{array}{r}0.01 \\
(1.59)\end{array}$ & $\begin{array}{r}0.14^{* * *} \\
(5.99)\end{array}$ & - \\
\hline $\begin{array}{l}\text { Lagged Investment } \\
\text { rate }\end{array}$ & $\begin{array}{l}0.12^{* *} \\
(2.39)\end{array}$ & $\begin{array}{r}0.09^{* * *} \\
(2.78)\end{array}$ & $\begin{array}{r}0.10^{* * * *} \\
(2.99)\end{array}$ & $\begin{array}{l}0.06^{* *} \\
(2.44)\end{array}$ & $\begin{array}{r}0.06 \\
(0.93)\end{array}$ \\
\hline Lagged fertility rate & $\begin{array}{r}-0.15 \\
(-1.37)\end{array}$ & $\begin{array}{r}-0.09 \\
(-1.46)\end{array}$ & $\begin{array}{l}-0.10^{*} \\
(-1.86)\end{array}$ & $\begin{array}{l}-0.05^{*} \\
(-1.90)\end{array}$ & $\begin{array}{r}-0.26^{* * *} \\
(-4.60)\end{array}$ \\
\hline $\begin{array}{l}\text { Lagged adult } \\
\text { mortality }\end{array}$ & $\begin{array}{l}-0.25^{* *} \\
(-2.52)\end{array}$ & $\begin{array}{l}-0.20^{* * *} \\
(-2.73)\end{array}$ & $\begin{array}{l}-0.20^{* * *} \\
(-2.70)\end{array}$ & $\begin{array}{r}-0.06 \\
(-1.46)\end{array}$ & $\begin{array}{r}0.04 \\
(0.73)\end{array}$ \\
\hline Lagged CVD & $\begin{array}{r}2.02^{* * *} \\
(3.31)\end{array}$ & $\begin{array}{l}0.92^{* *} \\
(2.46)\end{array}$ & $\begin{array}{l}1.05^{* *} \\
(2.48)\end{array}$ & $\begin{array}{l}0.41^{* *} \\
(2.20)\end{array}$ & $\begin{array}{r}0.83^{* * *} \\
(2.77)\end{array}$ \\
\hline Interaction & $\begin{array}{c}-0.22^{* * *} \\
(-3.28) \\
\end{array}$ & $\begin{array}{l}-0.09^{* *} \\
(-2.27) \\
\end{array}$ & $\begin{array}{l}-0.11^{* *} \\
(-2.35) \\
\end{array}$ & $\begin{array}{l}-0.04^{* *} \\
(-2.08) \\
\end{array}$ & $\begin{array}{r}-0.10^{* * *} \\
(-2.98) \\
\end{array}$ \\
\hline $\begin{array}{l}\text { Income threshold } \\
\text { Hansen-Test } \\
\text { AR1 } \\
\text { AR2 } \\
\text { \# observations }\end{array}$ & $\begin{array}{c}9719 \\
0.19 \\
0.06^{*} \\
0.05^{*} \\
286\end{array}$ & $\begin{array}{r}16178 \\
0.96 \\
0.08^{*} \\
0.10^{*} \\
320\end{array}$ & $\begin{array}{r}14475 \\
0.96 \\
0.07^{*} \\
0.09^{*} \\
320\end{array}$ & $\begin{array}{r}14408 \\
- \\
- \\
- \\
341\end{array}$ & $\begin{array}{r}4578 \\
- \\
- \\
- \\
341\end{array}$ \\
\hline \multicolumn{6}{|c|}{$\begin{array}{l}\text { Remarks: z-values applying Arellano (1987) covariance matrix in parenthesis; }{ }^{*},{ }^{* *},{ }^{* * *} \text { denotes significance } \\
\text { level at the } 10,5 \text {, and } 1 \% \text { level respectively; AR1 test on first order autocorrelation - p-value; AR2 test on } \\
\text { second order autocorrelation p-value; heteroscedasticity consistent Hansen-test on overidentifying resrictions p- }\end{array}$} \\
\hline
\end{tabular}

The estimated coefficients have all the expected signs. However, some control variables are not or only weakly significant. The coefficient on lagged income appears fairly large with 
large standard error. However, one needs to be careful not to mistake this coefficient for the convergence rate, since lagged income also appears in the interaction term.

Turning to our variable of interest, the CVD variable and its interaction term are both significant at the $1 \%$ level. At a threshold level of income below 9719 PPP US \$, there is a positive impact of CVD mortality rates on growth, and above this threshold there is a negative relation. Such an income threshold is also found in Bhargava et al. (2001) with respect to adult survival rates. However, the income threshold for adult survival rates is much lower seperating poor from middle and high income countries, while the threshold for CVD seperates rich from middle and poor income countries in the classification of the World Bank.

One needs to be careful in interpreting the relation of CVD and growth for three reasons. First, the test of second order autocorrelation of the estimated error term is weakly significant. This may render the covariate coefficient estimates inconsistent. Second, there may be reverse causality. Higher income growth may induce more luxury good consumption, which in turn could increase CVD mortality rates. Third, it may still be the case that there is no significant relation in one of the two sample halves, because the inclusion of the interaction term allows for a limited non-linearity only. In what follows we address all of these three possibilities.

First, we allow for endogeneity of the CVD variable and its interaction term in specification (2). This excludes any inconsistency from reversed causality as long as there is no correlation of future values of CVD on todays error term in estimating growth. The income elasticity of CVD mortality rates is reduced by half. Hence, reversed causality is likely to exist, but cannot explain the correlation of CVD and economic growth alone. 
So far, the estimates rely on large sample theory. In specification (3), we apply the more efficient two stage GMM estimator with small sample correction from Windmeijer (2000). Again, we do not observe any significant changes in results and obtain very similar estimates in magnitude.

To finally have a comparison, we also apply in specification (4) an inconsistent OLS estimator and in specification (5) an inconsistent FE estimator. The t-values in parenthesis are calculated in both cases using an autocorrelation and heteroscedasticity consistent covariance matrix estimate of Arellano (1987). Since the openness variable from Gallup and Sachs (1998) has no time variation, it drops out in the FE specification. While coefficients are different in magnitude indicating the presence of a bias, the CVD variable and its interaction term remain significant in all specifications.

When considering the implied income threshold at which there is a positive/negative correlation of CVD and income growth, the GMM estimators are in between the OLS and FE estimator. The implied threshold of the GMM estimators in roughly in the range that devides rich OECD and non-OECD from middle income countries according to the World Bank classification. For this reason, we continue analysing the rich-country sub-sample.

When restricting the sample size, different control variables become relevant. Since the rich countries have unconstrained access to the international capital market, the fertility rate and the investment rate are no longer determinants of income growth. The fertility rate influences income growth, because, when entering the labor market, the newly born cohort needs to be endowed with capital to keep the capital intensity constant. This additional need for capital formation reduces the rate of net investment at a given savings rate in a closed economy. However, whenever there is access to an international capital markets, the additional capital 
formation can be financed from abroad without being constrained by the domestic savings rate. In a similar vein, the investment rate is equal to the savings rate in a closed economy. Hence, economies with smaller savings rates invest less and grow less (Feldstein and Horioka, 1980). This relation breaks down, when there is access to the international capital market.

Table 4: OECD Sample

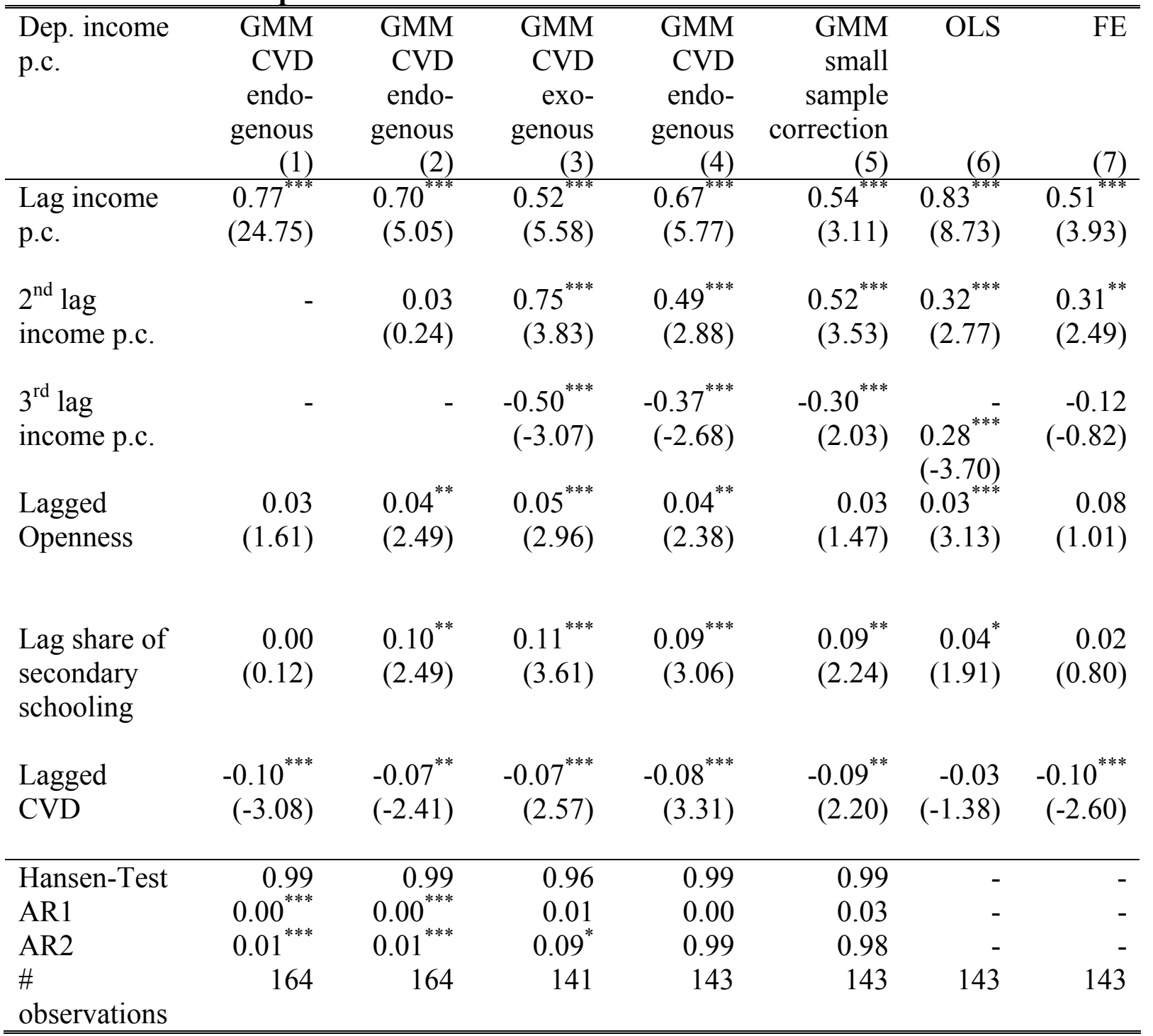

Remarks: z-values applying Arellano (1987) covariance matrix in parenthesis; ${ }^{*}, * *, * * *$ denotes significance level at the 10,5, and $1 \%$ level respectively; AR1 test on first order autocorrelation - p-value; AR2 test on second order autocorrelation p-value; heteroscedasticity consistent Hansen-test on overidentifying resrictions pvalue; Constant term not reported; 
Indeed, the investment rate and the fertility rate turn out to be insignificant on the sub-sample of rich countries. In addition, the openness variable of Gallup and Sachs (1998) is also insignificant, which may be due to the lack of time variation of this variable. Instead, we apply the openness variable from the Penn World Tables, which is defined as the sum of imports and exports divided by GDP. Since GDP is part of the construction of the openness variable from the Penn World Tables, we will treat this variable as endogenous in GMM estimations. In addition, the share of the working age population with secondary education becomes a significant determinant of income growth, because human capital - unlike physical capital - is typically not mobile internationally. ${ }^{15}$

Table 4 displays the results on the rich-country sub-sample. First, we note that in specification (1) the CVD variable is highly significant with negative sign, when applying a GMM-one step estimator with endogenous CVD variable. Unfortunately, the autocorrelation test of second order indicates severe problems of autocorrelation, which renders the estimator inconsistent. To avoid this misspecification problem, we add in specification (2) an additional time lag of the dependent variable as covariate, but the autocorrelation problem remains. Since there is an additional lag of the dependent variable, all instruments are lagged by one more time, too, to avoid correlation of the instruments with the error term.

Only, when we also add the third 5-year time lag of the dependent variable in specification (3), the problem of autocorrelation of the error term is substantially reduced. Still, when the CVD variable is assumed exogenous, there is autocorrelation at the $10 \%$ significance level. However, specification (4) endogenizes the CVD variable and the autocorrelation problem disappears. Hence, we consider this specification as our baseline, since it seems to be well specified: besides lack of autocorrelation of second order, the Hansen test of overidentifying

\footnotetext{
${ }^{15}$ Bhargava et al. (2001) have pointed out that human capital measures are not significant in a panel data set with more countries.
} 
restrictions is passed and the estimated coefficients are all significant with expected signs. For example, larger openness and a larger stock of human capital increase income growth.

Our variable of interest, CVD, is also highly significant at the 5\% level. An increase in the mortality rate by $1 \%$ decreases the per capita income growth rate by about one promille point. This is a small amount in terms of growth rates, but a large amount in money terms when summed up over the lifetime of an economy.

Since the number of rich countries is rather small, it is important to apply the small sample correction of Windmeijer (2000) to the covariance estimates. Specification (5) displays the results. While openness becomes insignificant mainly due to a larger standard error, all other estimates remain significant.

Finally, we report for the sake of comparison the estimates of an inconsistent OLS and FE estimator in specifications (6) and (7), respectively. While the magnitude of coefficients varies at times substantially indicating a presence of bias, the qualitative results remain the same, although the CVD variable is insignificant in the OLS specification.

Since there seems to be a cyclical component in GDP growth data of a rather large wave length which seems puzzling at first glance, we also investigate the same data annually. To be able to do this, we need to interpolate the secondary schooling share variable first. Then, we find that autocorrelation disappears only if we include time lags of the dependent variable for the first four years, the $10^{\text {th }}$ year and the $15^{\text {th }}$ year both for the entire sample and the richcountry sub-sample ${ }^{16}$. Hence, the rather large cyclical pattern in the data is not an artefact of choosing five-year growth rates in the previous analysis. The first four year time lags

\footnotetext{
${ }^{16}$ The results are not reported, but available from the authors upon request.
} 
probably capture business cycle components of GDP growth. The larger lag length of 10 and 15 years may be explained by Kondratieff-type technology waves.

Next, we investigate the omitted variable problem. It may be that CVD mortality rates are correlated to an omitted variable that causes itself economic growth. For example, CVD mortality rates may be larger in societies with bad health systems which in turn may decrease the working moral, productivity, rate of return to investment, and eventually economic growth. Alternatively, it may be the case that the quality of the health system in general is itself a proxy variable for the quality of public intermediate goods supply. Finally, it may be a proxy for the innovative capability of an economy.

For this reason, we apply a number of alternative measures of the health system as control variables. Since an additional variable implies an additional regression coefficient that must be estimated, the number of moment restrictions will be insufficient to have several time lags of the instruments. In order to avoid inefficiency of the estimates, when using only one instrument, we refer to the specification, when the CVD variable is assumed exogenous and the two first valid lacks of the instruments are applied. This procedure is justifiable, because we found in specifications (3) and (4) of Table 4 that the magnitude of the coefficient of the CVD variable is very similar in both cases.

In Table 5, specification (1), we add the control variable adult mortality rate that has been used before already in Table 3. Next, we add the logarithm of the number of doctors per population in specification (2). The density of doctors can be thought of as a control for the coverage of the health system. In specification (3), we add the logarithm of the lagged mortality rate caused by injuries to control alternatively for the quality of the health system. 
Specifications (4) and (5) eventually control for the lagged logarithm of the old age

Table 5: Control variables OECD sample

\begin{tabular}{|c|c|c|c|c|c|}
\hline Dep. income p.c. & $\begin{array}{r}\text { GMM } \\
\text { CVD } \\
\text { exogenous } \\
(1)\end{array}$ & $\begin{array}{r}\text { GMM } \\
\text { CVD } \\
\text { exogenous } \\
(2)\end{array}$ & $\begin{array}{r}\text { GMM } \\
\text { CVD } \\
\text { exogenous } \\
(3)\end{array}$ & $\begin{array}{r}\text { GMM } \\
\text { CVD } \\
\text { exogenous } \\
(4)\end{array}$ & $\begin{array}{r}\text { GMM } \\
\text { CVD } \\
\text { exogenous } \\
(5)\end{array}$ \\
\hline Lagged income p.c. & $\begin{array}{c}0.52^{* * * *} \\
(5.23)\end{array}$ & $\begin{array}{c}0.61^{* * *} \\
(7.40)\end{array}$ & $\begin{array}{r}0.54^{* * * *} \\
(5.08)\end{array}$ & $\begin{array}{c}0.41^{* * *} \\
(3.46)\end{array}$ & $\begin{array}{c}0.44^{* * * *} \\
(4.81)\end{array}$ \\
\hline $2^{\text {nd }}$ lag income p.c. & $\begin{array}{r}0.73^{* * *} \\
(3.95)\end{array}$ & $\begin{array}{r}0.60^{* * *} \\
(3.56)\end{array}$ & $\begin{array}{r}0.72^{* * *} \\
(3.80)\end{array}$ & $\begin{array}{r}0.77^{* * *} \\
(4.22)\end{array}$ & $\begin{array}{r}0.76^{* * *} \\
(4.55)\end{array}$ \\
\hline $3^{\text {rd }}$ lag income p.c. & $\begin{array}{c}-0.48^{* * *} \\
(2.95)\end{array}$ & $\begin{array}{r}-0.40^{* *} \\
(2.27)\end{array}$ & $\begin{array}{r}-0.49^{* * *} \\
(2.82)\end{array}$ & $\begin{array}{l}-0.37^{*} \\
(1.92)\end{array}$ & $\begin{array}{c}-0.43^{* * *} \\
(-3.32)\end{array}$ \\
\hline Lagged openness & $\begin{array}{r}0.05 \\
(2.75)\end{array}$ & $\begin{array}{r}0.04 \\
(2.32)\end{array}$ & $\begin{array}{r}0.05^{* * *} \\
(3.15)\end{array}$ & $\begin{array}{r}0.03 \\
(1.13)\end{array}$ & $\begin{array}{r}0.07^{* * * *} \\
(3.17)\end{array}$ \\
\hline $\begin{array}{l}\text { Lagged secondary } \\
\text { schooling share }\end{array}$ & $\begin{array}{l}0.11^{* *} \\
(3.69)\end{array}$ & $\begin{array}{l}0.09^{* *} \\
(2.55)\end{array}$ & $\begin{array}{r}0.11^{* * * *} \\
(3.67)\end{array}$ & $\begin{array}{r}0.10^{* * *} \\
(2.94)\end{array}$ & $\begin{array}{c}0.10^{* * *} \\
(3.80)\end{array}$ \\
\hline Lagged CVD & $\begin{array}{r}-0.07^{* *} \\
(1.96)\end{array}$ & $\begin{array}{l}-0.07^{* *} \\
(2.44)\end{array}$ & $\begin{array}{r}-0.07^{* *} \\
(2.03)\end{array}$ & $\begin{array}{r}-0.07^{* *} \\
(2.06)\end{array}$ & $\begin{array}{r}-0.19^{* * *} \\
(2.60)\end{array}$ \\
\hline Lagged mortality rate & $\begin{array}{r}-0.02 \\
(-0.28)\end{array}$ & - & - & - & - \\
\hline $\begin{array}{l}\text { Lagged density of } \\
\text { doctors }\end{array}$ & - & $\begin{array}{r}-0.04 \\
(0.99)\end{array}$ & - & - & - \\
\hline $\begin{array}{l}\text { Lagged injury } \\
\text { mortality rate }\end{array}$ & - & - & $\begin{array}{r}-0.01 \\
(-0.13)\end{array}$ & - & - \\
\hline $\begin{array}{l}\text { Lagged old age } \\
\text { dependency ratio }\end{array}$ & - & - & - & $\begin{array}{l}-0.13^{*} \\
(1.76)\end{array}$ & - \\
\hline $\begin{array}{l}\text { Lagged non- } \\
\text { communicable } \\
\text { desease mortality rate }\end{array}$ & - & - & - & - & $\begin{array}{l}0.23^{*} \\
(1.78)\end{array}$ \\
\hline $\begin{array}{l}\text { Hansen-Test } \\
\text { AR1 } \\
\text { AR2 } \\
\text { \# observations }\end{array}$ & $\begin{array}{r}0.97 \\
0.02^{* *} \\
0.11 \\
141 \\
\end{array}$ & $\begin{array}{r}0.97 \\
0.01^{* * *} \\
0.40 \\
130 \\
\end{array}$ & $\begin{array}{r}0.95 \\
0.01^{* *} \\
0.07^{*} \\
141 \\
\end{array}$ & $\begin{array}{r}0.98 \\
0.03 \\
0.10^{*} \\
141 \\
\end{array}$ & $\begin{array}{r}0.98 \\
0.02 \\
0.07 \\
141 \\
\end{array}$ \\
\hline
\end{tabular}

Remarks: z-values applying Arellano (1987) covariance matrix in parenthesis; $*, * *, * * *$ denotes significance level at the 10,5, and $1 \%$ level respectively; AR1 test on first order autocorrelation - p-value; AR2 test on second order autocorrelation p-value; heteroscedasticity consistent Hansen-test on overidentifying resrictions pvalue; Constant term not reported; 
dependency rate, which may control for the innovative potential of an economy, and the lagged value of the mortality rate caused by non-communicable diseases to ensure that indeed cardiovascular disease is responsible for the relation with economic growth.

In all cases, the CVD variable remains significant at the 5\% level, while most of the control variables are not. The only exception is the old age dependency rate. Aging economies tend to grow slower. Overall, weak problems of autocorrelation remain in some specifications. Since the estimated coefficient of CVD remains remarkably stable over all specifications (with and without weak autocorrelation problems), we do not observe any substantial bias of its estimates even in the presence of weak autocorrelation.

We also tried all estimates of Table 5 assuming the CVD variable to be endogenous ${ }^{17}$. The CVD variable was always highly significant, but some other control variables became insignificant occasionally and some signs of control variables were not as expected.

Finally, we investigate whether the CVD variable really does have the opposite sign in the sub-sample of middle and low-income countries (results not reported, but available on request). However, we find that no significant relationship exists in this sub-sample. Hence, any negative impact of CVD on economic growth is only significant if income levels are sufficiently high.

\section{Conclusion}

The present paper has provided what is to the best of our knowledge the first attempt to assess the impact of cardiovascular disease on economic growth, using a growth regression framework. We used state-of-the-art methodology to address the most salient technical

\footnotetext{
${ }^{17}$ The results are not reported but available from the authors upon request.
} 
problems that could be addressed. There remains, however, a general concern about the application of the growth regression methodology (Durlauf, 2001). Data limitations matter, too: CVD mortality data, which we constructed on the basis of the WHO Mortality Database, is missing for many low-income countries, and where data is available, it is of significantly worse quality in the low- and middle-income countries compared to the high-income countries (WHO 2006). Hence our findings for the latter group of countries can be considered much more reliable than those for the low- and middle-income countries.

Bearing in mind those reservations, the results suggest that CVDs are bad for growth, but only once the countries have reached a fairly high level of per capita income. It is not entirely surprising to note that CVDs have no statistically significant role in explaining growth differences between rich and poor countries in the time period examined (1960-2000). Too many other important factors distinguish the two country groups, and CVDs have only been emerging quite strongly in the later part of this period in developing countries. The result should therefore not be misinterpreted as a justification for complacency in the developing countries facing the fast growing burden of CVDs. Concern as for the potential future economic impact of CVDs in developing countries is particularly warranted in light of the fairly reliable prediction that not only the speed of the CVD epidemic in developing countries is likely to exceed that previously experienced by high-income-countries, but also that its adverse impacts are likely to be felt more strongly in the developing world (Schmidhuber and Shetty, 2005).

Our results also contribute to the relatively small literature on the role of health as a determinant of growth in high-income countries. As briefly mentioned above, the empirical evidence on the role of health in economic growth in rich countries has produced rather unsatisfactory and mixed results, not least depending on the choice of health proxy. The very 
few studies that used public health expenditure as a proxy for health did find a significant positive contribution to economic growth in high-income countries. However, in light of the poor empirical link between health expenditures and health outcomes (Anderson and Poullier, 1999), one may have reason to question the interpretation of the results (Rivera and Currais (1999a, b), Knowles and Owen $(1995,1997))$. In contrast, studies that used life expectancy as a proxy for health generally failed to find a significant impact on growth, and where the impact was significant, it was commonly of a negative sign.

Our findings suggest that part of the ambiguous results may indeed be due to the choice of health proxy. As life expectancy varies very little between rich countries, it is not surprising to find that its explanatory power is highly limited. CVD-mortality (at working age) does vary more markedly between rich countries and therefore represents a more "appropriate" indicator to quantify existing health differences between rich countries. Nevertheless, the present study has only taken a first step towards an improved understanding of the "true" role of health in rich countries' medium and long term growth performance. For certain, in order to better understand the contribution of health to economic development in rich countries, there is a critical need to go beyond the most general health indicators that have traditionally been applied in the developing country literature. 


\section{Appendix}

Table A 1: Summary Statistics - Full sample and Rich Country Sample

\begin{tabular}{|c|c|c|c|c|c|}
\hline Variable name & $\begin{array}{l}\text { \# observa- } \\
\text { tions }\end{array}$ & Mean & Std. dev. & Min & Max \\
\hline GDP p.c. & 341 & 11365.32 & 6916.805 & 1369.589 & 33308.4 \\
\hline $1^{\text {st }}$ lag GDP p.c. & 341 & 10109.32 & 6229.086 & 1121.392 & 28409.62 \\
\hline Open 1965-90 & 341 & 0.5822242 & .4552672 & 0 & 1 \\
\hline Investment rate & 341 & 20.90187 & 8.594127 & 3.249018 & 68.34639 \\
\hline Fertility rate & 341 & 2.968865 & 1.572043 & 1.18 & 7.4168 \\
\hline Adult mortality rate & 341 & .011316 & .0044232 & .0052631 & .0375629 \\
\hline CVD mortality rate & 341 & 134.7982 & 65.41324 & 32.61629 & 390.1721 \\
\hline Openness & 143 & 60.18594 & 47.53438 & 10.86745 & 301.3148 \\
\hline $\begin{array}{l}\text { Secondary education }- \text { total } \\
\text { stock }\end{array}$ & 143 & 36.58671 & 12.75781 & 6.8 & 69.6 \\
\hline Density of physicians & 135 & 2.079481 & .7873906 & .6569 & 4.7 \\
\hline $\begin{array}{l}\text { Injury mortality rate - } \\
\text { working age }\end{array}$ & 143 & 55.79993 & 16.82787 & 26.05 & 101.93 \\
\hline Old age dependency rate & 143 & .1191733 & .0299058 & .033502 & .1777936 \\
\hline $\begin{array}{l}\text { Non-communicable disease } \\
\text { mortality rate }\end{array}$ & 143 & 292.5629 & 64.62071 & 160.1588 & 470.0503 \\
\hline
\end{tabular}

\section{Data coverage}

Baseline Specification for Table 3 - Full sample.

Argentina, Armenia, Australia, Austria, Azerbaijan, Belgium, Bulgaria, Belarus, Belize, Brazil, Barbados, Canada, Switzerland, Chile, China, Colombia, Costa Rica, Cuba, Czech Republic, Germany (united after 1990), Denmark, Dominican Republic, Ecuador, Egypt, Spain, Estonia, Finland, France, UK, Greece, Guatemala, Hong Kong, Honduras, Croatia, Hungary, Ireland, Iceland, Israel, Italy, Jamaica, Japan, Kazakhstan, Kyrgyzstan, Republic Korea, Sri Lanka, Lithuania, Luxembourg, Latvia, Moldova, Mexico, Mauritius, Netherlands, Norway, New Zealand, Panama, Philippines, Poland, Puerto Rico, Portugal, Paraguay, Romania, Russia, Singapore, El Salvador, Slovenia, Sweden, Syria, Thailand, Trinidad and Tobago, Ukraine, Uruguay, USA, Venezuela.

Baseline specification for Table 4 and 5 - high income and higher-middle income countries according to World Bank classification.

Australia, Austria, Belgium, Canada, Czech Republic, Germany (united from 1990),

Denmark, Spain, Finland, France, UK, Greece, Hong Kong, Irland, Isalnd, Israel, Italy, Japan, Netherlands, Norway, New Zealand, Protugal, Singapore, Sweden, USA. 


\section{References}

Anderson, G.F. and Poullier, J.P. (1999) "Health Spending, Access, and Outcomes: Trends in Industrialized Countries," Health Affairs (May/June): pp. 178-187.

Acemoglu, Daron, and Simon Johnson, 2006, Disease and development: the effect of life expectancy on growth. http://economics.uchicago.edu/Acemoglu_042506.pdf(accessed 17 May 2006)

Arellano, Manuel, 1987, Computing robust standard errors for within-groups estimators, Oxford Bulletin of Economics and Statistics, Vol. 49, No. 4, pp. 431-434.

Arellano, Manuel, und Stephen R. Bond, 1991, Some tests of specification for panel data: Monte Carlo evidence and an application to employment equations, Review of Economic Studies, Vol. 58, pp. 277-297.

Barro, Robert J. and Jong-Wha Lee, 2000, International Data on Educational Attainment: Updates and Implications, Center for International Development, Working Paper no. 42, Harvard University.

Beraldo, S., Montolio, D. and Turati, G. (2005), Healthy, educated and wealthy: is the welfare state really harmful for growth?,Working Papers in Economics 127, Barcelona: Universitat de Barcelona, Espai de Recerca en Economia.

Bhargava, Alok, and J.D. Sargan, 1983, Estimating dynamic random effects models from panel data covering short time periods, Econometica, Vol. 51, pp. 1635-60.

Bhargava, Alok, Dean T. Jamison, Lawrence J. Lau, and Christopher J.L. Murray, 2001, Modeling the effects of health on economic growth, Journal of Health Economics, Vol. 20, pp. 423-40.

Binder, Michael, Cheng Hsiao und M. Hshem Pesaran, 2003, Estimation and Inference in Short Panel Vector Autoregressions with Unit Roots and Cointegration, manuscript.

Blundell, Richard, und Stephen Bond, 1998, Initial Conditions and moment restrictions in dynamic panel data models, Journal of Econometrics, Vol. 87, pp. 115-143.

Bond, Stephen R., Anke Hoeffler und Jonathan Temple, 2001, GMM estimation of empirical growth models, CEPR Discussion Papers No. 3048.

Bond, Stephen, Celine Nauges, und Frank Windmeijer, 2002, Unit roots and identification in autoregressive panel data models: A comparison of alternative tests, Institute for Fiscal Studies London, manuscript.

López-Casasnovas, G.; Rivera, B.; and Currais L. (eds.) (2005), Health and economic growth: findings and policy implications, MIT Press: Cambridge/MA.

Caselli, F., G. Esquivell, and F. Lefort, 1996, Reopening the convergence debate: a new look at cross-country growth empirics, Journal of Economic Growth, Vol. 1, pp. 363-89.

Commission on Macroeconomics and Health (2001), Macroeconomics and health: investing in health for economic development, report of the Commission on Macroeconomics and Health, chaired by Jeffrey Sachs, Geneva: Commission on Macroeconomics and Health.

Delfino, D.; and P. J. Simmons (1999) "Infectious Disease and Economic Growth: the Case of Tuberculosis" University of York Discussion Papers in Economics, No. 1999/23.

Dixon, S.; S. McDonald, and J. Roberts (2001) "AIDS and economic growth in Africa: a panel data analysis" Journal of International Development, Vol. 13(4): pp. 411-426.

Durlauf, S.N., 2001, Manifesto for a growth econometrics, Journal of Econometrics 100: 6569. 
Ezzati M, Vander Hoorn S, Lawes CM, Leach R, James WP, Lopez AD (2005) "Rethinking the "diseases of affluence" paradigm: global patterns of nutritional risks in relation to economic development". PLoS Medicine. May;2(5):e133.

Feldstein, Martin, and Charles Horioka, 1980, Domestic savings and international capital flows, Economic Journal, Vol. 90, pp. 314-29.

Gallup, J.L., and J.D. Sachs, 1998, Geography and economic development, Discussion Paper, Center for International Development, Harvard University, Cambridge MA.

Hahn, Jinyong, and Jerry Hausman, 2002, A new specification test for the validity of instrumental variables, Vol. 70, No. 1, pp. 163-89.

Islam, Nazrul, 1995, Growth empirics: a panel data approach, Quarterly Journal of Economics, Vol. 110, No. 4, pp. 1127-70.

Jamison, D. T., et al (2006) "Disease control priorities $n$ developing countries" $2^{\text {nd }}$ ed. New York: Oxford University Press.

Kalemli-Ozcan, S., H.E. Ryder, and D. Weil, 2000, Mortality decline, human capital investment, and economic growth, Journal of Development Economics, 62: 1-23.

Knowles, S. and Owen, P. (1995), 'Health capital in cross-country variation in income per capita in the Mankiw-Romer- Weil model', Economic Letters, 48: 99-106.

Knowles, S. and Owen, P. (1997), 'Education and health in an effective-labour empirical growth model', Economic Record, 73(223): 314-328.

Leeder S., S. Raymond, H. Greenberg, H. Liu, K. Esson (2004), A race against time: the challenge of cardiovascular disease in developing countries, The Earth Institute at Columbia University.

Levine, R. and D. Renelt. 1992. "A Sensitivity Analysis of Cross-Country Growth Regressions", American Economic Review, Vol. 82: pp. 942-63.

Mankiw, N. Gregory, David Romer, and David N. Weil, 1992, A contribution to the empirics of economic growth, Quarterly Journal of Economics, Vol. 107, pp. 407-37.

Nickel, Stephen S., 1981, Biases in dynamic models with fixed effects, Econometrica, Vol. 49, pp. 1117-26.

Petersen S, Peto V, Rayner M et al (2005). European cardiovascular disease statistics: 2005 editition. British Heart Foundation.

Rivera, B. and Currais, L. (1999a), 'Economic growth and health: direct impact or reverse causation?', Applied Economics Letters, 6: 761-764.

Rivera, B. and Currais, L. (1999b), 'Income variation and health expenditure: evidence for OECD countries', Review of Development Economics, 3(3): 258-267.

Roodman, David, 2003, Stata module: xtabond2, Center for Global Development, Washington D.C., http://ideas.repec.org/c/boc/bocode/s435901.html

Sachs, Jeffrey D. and John Luke Gallup. (2001) "The Economic Burden of Malaria." The Supplement to The American Journal of Tropical Medicine \& Hygiene, vol. 64, no. 1, 2, pp 85-96, January/February.

Sala-I-Martin, X., G. Doppelhofer and R. I. Miller. 2004. "Determinants of Long-Term Growth: A Bayesian Averaging of Classical Estimates (BACE) Approach", American Economic Review, Vol. 94(4): pp. 813-35.

Schmidhuber, J. and Shetty, P. (2005). The nutrition transition to 2030 - why developing countries are likely to bear the major burden. EAAE plenary paper, Reading, 2005.

Staiger, Douglas, and James H. Stock, 1997, Instrumental variables regression with weak instruments, Econometrica, Vol. 65, pp. 557-86.

Suhrcke M., D. Stuckler, S. Leeder et al (2005) "The economic consequences of chronic disease and the economic rationale for public and private intervention", Oxford Health Alliance.

Soares, R.R. (2005). Mortality Reductions, Educational Attainment, and Fertility Choice. American Economic Review, 95(3), June, pp. 580-601. 
Trognon, Alain, 1978, Miscellaneous asymptotic properties of ordinary least squares and maximum likelihood estimators in dynamic error components models, Annales d l'INSEE, Vol. 30/31, pp. 631-657.

Weil, D. (2005) "Accounting for the Effect of Health on Economic Growth", NBER Working Paper No. 11455 ,

WHO (2005) "Preventing chronic disease: a vital investment" World Health Organization: Geneva.

WHO (2006). Global Burden of Disease website. http://www3.who.int/whosis/menu.cfm?path=whosis,bod,burden,burden_estimates\&la nguage $=$ english

Windmeijer, Frank, 2000, A finite sample correction for the variance of linear GMM two-step estimators, Institute for Fiscal Studies WP 00/19. 


\section{CESifo Working Paper Series}

(for full list see www.cesifo-group.de)

1784 Paolo M. Panteghini, A Simple Explanation for the Unfavorable Tax Treatment of Investment Costs, August 2006

1785 Alan J. Auerbach, Why have Corporate Tax Revenues Declined? Another Look, August 2006

1786 Hideshi Itoh and Hodaka Morita, Formal Contracts, Relational Contracts, and the Holdup Problem, August 2006

1787 Rafael Lalive and Alejandra Cattaneo, Social Interactions and Schooling Decisions, August 2006

1788 George Kapetanios, M. Hashem Pesaran and Takashi Yamagata, Panels with Nonstationary Multifactor Error Structures, August 2006

1789 Torben M. Andersen, Increasing Longevity and Social Security Reforms, August 2006

1790 John Whalley, Recent Regional Agreements: Why so many, why so much Variance in Form, why Coming so fast, and where are they Headed?, August 2006

1791 Sebastian G. Kessing and Kai A. Konrad, Time Consistency and Bureaucratic Budget Competition, August 2006

1792 Bertil Holmlund, Qian Liu and Oskar Nordström Skans, Mind the Gap? Estimating the Effects of Postponing Higher Education, August 2006

1793 Peter Birch Sørensen, Can Capital Income Taxes Survive? And Should They?, August 2006

1794 Michael Kosfeld, Akira Okada and Arno Riedl, Institution Formation in Public Goods Games, September 2006

1795 Marcel Gérard, Reforming the Taxation of Multijurisdictional Enterprises in Europe, a Tentative Appraisal, September 2006

1796 Louis Eeckhoudt, Béatrice Rey and Harris Schlesinger, A Good Sign for Multivariate Risk Taking, September 2006

1797 Dominique M. Gross and Nicolas Schmitt, Why do Low- and High-Skill Workers Migrate? Flow Evidence from France, September 2006

1798 Dan Bernhardt, Stefan Krasa and Mattias Polborn, Political Polarization and the Electoral Effects of Media Bias, September 2006 
1799 Pierre Pestieau and Motohiro Sato, Estate Taxation with Both Accidental and Planned Bequests, September 2006

1800 Øystein Foros and Hans Jarle Kind, Do Slotting Allowances Harm Retail Competition?, September 2006

1801 Tobias Lindhe and Jan Södersten, The Equity Trap, the Cost of Capital and the Firm's Growth Path, September 2006

1802 Wolfgang Buchholz, Richard Cornes and Wolfgang Peters, Existence, Uniqueness and Some Comparative Statics for Ratio- and Lindahl Equilibria: New Wine in Old Bottles, September 2006

1803 Jan Schnellenbach, Lars P. Feld and Christoph Schaltegger, The Impact of Referendums on the Centralisation of Public Goods Provision: A Political Economy Approach, September 2006

1804 David-Jan Jansen and Jakob de Haan, Does ECB Communication Help in Predicting its Interest Rate Decisions?, September 2006

1805 Jerome L. Stein, United States Current Account Deficits: A Stochastic Optimal Control Analysis, September 2006

1806 Friedrich Schneider, Shadow Economies and Corruption all over the World: What do we really Know?, September 2006

1807 Joerg Lingens and Klaus Waelde, Pareto-Improving Unemployment Policies, September 2006

1808 Axel Dreher, Jan-Egbert Sturm and James Raymond Vreeland, Does Membership on the UN Security Council Influence IMF Decisions? Evidence from Panel Data, September 2006

1809 Prabir De, Regional Trade in Northeast Asia: Why do Trade Costs Matter?, September 2006

1810 Antonis Adam and Thomas Moutos, A Politico-Economic Analysis of Minimum Wages and Wage Subsidies, September 2006

1811 Guglielmo Maria Caporale and Christoph Hanck, Cointegration Tests of PPP: Do they also Exhibit Erratic Behaviour?, September 2006

1812 Robert S. Chirinko and Hisham Foad, Noise vs. News in Equity Returns, September 2006

1813 Oliver Huelsewig, Eric Mayer and Timo Wollmershaeuser, Bank Behavior and the Cost Channel of Monetary Transmission, September 2006

1814 Michael S. Michael, Are Migration Policies that Induce Skilled (Unskilled) Migration Beneficial (Harmful) for the Host Country?, September 2006 
1815 Eytan Sheshinski, Optimum Commodity Taxation in Pooling Equilibria, October 2006

1816 Gottfried Haber and Reinhard Neck, Sustainability of Austrian Public Debt: A Political Economy Perspective, October 2006

1817 Thiess Buettner, Michael Overesch, Ulrich Schreiber and Georg Wamser, The Impact of Thin-Capitalization Rules on Multinationals' Financing and Investment Decisions, October 2006

1818 Eric O’N. Fisher and Sharon L. May, Relativity in Trade Theory: Towards a Solution to the Mystery of Missing Trade, October 2006

1819 Junichi Minagawa and Thorsten Upmann, Labor Supply and the Demand for Child Care: An Intertemporal Approach, October 2006

1820 Jan K. Brueckner and Raquel Girvin, Airport Noise Regulation, Airline Service Quality, and Social Welfare, October 2006

1821 Sijbren Cnossen, Alcohol Taxation and Regulation in the European Union, October 2006

1822 Frederick van der Ploeg, Sustainable Social Spending in a Greying Economy with Stagnant Public Services: Baumol’s Cost Disease Revisited, October 2006

1823 Steven Brakman, Harry Garretsen and Charles van Marrewijk, Cross-Border Mergers \& Acquisitions: The Facts as a Guide for International Economics, October 2006

1824 J. Atsu Amegashie, A Psychological Game with Interdependent Preference Types, October 2006

1825 Kurt R. Brekke, Ingrid Koenigbauer and Odd Rune Straume, Reference Pricing of Pharmaceuticals, October 2006

1826 Sean Holly, M. Hashem Pesaran and Takashi Yamagata, A Spatio-Temporal Model of House Prices in the US, October 2006

1827 Margarita Katsimi and Thomas Moutos, Inequality and the US Import Demand Function, October 2006

1828 Eytan Sheshinski, Longevity and Aggregate Savings, October 2006

1829 Momi Dahan and Udi Nisan, Low Take-up Rates: The Role of Information, October 2006

1830 Dieter Urban, Multilateral Investment Agreement in a Political Equilibrium, October 2006

1831 Jan Bouckaert and Hans Degryse, Opt In Versus Opt Out: A Free-Entry Analysis of Privacy Policies, October 2006 
1832 Wolfram F. Richter, Taxing Human Capital Efficiently: The Double Dividend of Taxing Non-qualified Labour more Heavily than Qualified Labour, October 2006

1833 Alberto Chong and Mark Gradstein, Who's Afraid of Foreign Aid? The Donors' Perspective, October 2006

1834 Dirk Schindler, Optimal Income Taxation with a Risky Asset - The Triple Income Tax, October 2006

1835 Andy Snell and Jonathan P. Thomas, Labour Contracts, Equal Treatment and WageUnemployment Dynamics, October 2006

1836 Peter Backé and Cezary Wójcik, Catching-up and Credit Booms in Central and Eastern European EU Member States and Acceding Countries: An Interpretation within the New Neoclassical Synthesis Framework, October 2006

1837 Lars P. Feld, Justina A.V. Fischer and Gebhard Kirchgaessner, The Effect of Direct Democracy on Income Redistribution: Evidence for Switzerland, October 2006

1838 Michael Rauscher, Voluntary Emission Reductions, Social Rewards, and Environmental Policy, November 2006

1839 Vincent Vicard, Trade, Conflicts, and Political Integration: the Regional Interplays, November 2006

1840 Erkki Koskela and Mikko Puhakka, Stability and Dynamics in an Overlapping Generations Economy under Flexible Wage Negotiation and Capital Accumulation, November 2006

1841 Thiess Buettner, Michael Overesch, Ulrich Schreiber and Georg Wamser, Taxation and Capital Structure Choice - Evidence from a Panel of German Multinationals, November 2006

1842 Guglielmo Maria Caporale and Alexandros Kontonikas, The Euro and Inflation Uncertainty in the European Monetary Union, November 2006

1843 Jan K. Brueckner and Ann G. Largey, Social Interaction and Urban Sprawl, November 2006

1844 Eytan Sheshinski, Differentiated Annuities in a Pooling Equilibrium, November 2006

1845 Marc Suhrcke and Dieter Urban, Are Cardiovascular Diseases Bad for Economic Growth?, November 2006 